\title{
MACROECONOMIC FACTORS AND STOCK PRICES - A CASE OF REAL ESTATE STOCKS ON HO CHI MINH STOCK EXCHANGE
}

\author{
Vo Thi Quy ${ }^{1 *}$, Dang Thi Ngoc Loi ${ }^{2}$ \\ ${ }^{1,2}$ International University, Vietnam National University HCMC. \\ *Email: vtquy@hcmiu.edu.vn
}

(Received: April 16, 2016; Revised: May 11, 2016; Accepted: May 17, 2016)

\begin{abstract}
This study investigates the relationship of selected economic factors such as inflation rate, 10-year Government bond yields, GDP growth rate, exchange rate, and stock trading volumes and real estate stock price of 38 real estate companies listed on HOSE in period 7 years, from January 2009 to September 2015.The study found that 3 economic factors (inflation rate, GDP growth rate, and exchange rate) impact significantly on real estate stock prices; but the relationship between 10-year Government bond yield and trading volume, and real estate stock prices was not found. The research's results imply that these factors should be taken into account as predictors of the movement of real estate stock price in Vietnamese stock market.
\end{abstract}

Keywords: Macroeconomic Factors; Market Factors; Stock Prices; Real Estate Companies; HOSE.

\section{Introduction to the research problem}

Since 1986 with the introduction of the Reform policy, Vietnamese Government has applied many different measures to speed up the development of Vietnamese economy. Before 2007, the average growth rate of GDP was around 7 percent. However, being negatively affected by the financial crisis originated from the US (October, 2008), the average growth rate of Vietnam GDP was around 6 percent in period from 2009 to 2014. Now, Vietnam has achieved significant breakthrough in the economic growth. Especially, in the last two quarters of year 2015, the GDP grew 6.47 percent and 6.81 percent, respectively. The inflation rate in the economy has decreased rapidly. It was 6.6 percent in 2013 and reduced to 4.09 percent in 2014. The figure released by General Statistics Office of Vietnam on 24 December
2015 was at a record low, 0.63 percent in 2015. At the same time, many Vietnamese real estate companies have faced to lot problems such as high inventory balance, and financial distress. To recover the real estate sector the Government tried to improve the legal framework and offered many bailouts, for example issuing the Real Estate Trading Law (No.66/2014/QH13), or the Law on Housing (No.65/2014/QH13). From 2014, real estate stocks belong to the most liquid stocks list of Ho Chi Minh Stock Exchange. Five of the ten most liquid stocks in 2014 are of real estate stocks - FLC, ITA, HAG, HQC, and $\mathrm{KBC}$ (Cafef.vn). The trading volume of real estate stocks account for about $18.7 \%$ with $12 \%$ of total market capitalization according to ViettinbankSc' s report (2015). In such a scene, a question may arise "How economic factors impact on the price of real 
estate stocks in Vietnamese stock exchange, and whether the relationship between trading volume of the stocks and their price exists?"

Actually many studies on the relationship between economic factors and stock prices have been conducted in different markets, however to our knowledge in Vietnam no study related to the research issue was conducted in real estate sector. Therefore, this research was conducted to understand the effect of economic factors and trading volume on stock price of 38 real estate companies listed in HOSE in the period from 209 to 2015. The research findings may bring about the meaningful implications to potential investors in real estate sector in the market.

\section{Literature review}

2.1. Selected macroeconomic factors and stock price movement

In the economic view, the presence of inflation affects companies' future cash flows because it influences on companies' revenue, operating costs, in turn they impact on companies' profit, return on equity, and existing projects' NPV. Many researchers have studied on the relationship of inflation and stock index and provided evidence of the existence of the relation. Pradhan, et. al., (2013) investigated the link between stock market and inflation of 16 Asia countries (HongKong SAR, China, India, Israel, Jordan, Korean, Pakistan, Sri Lanka, Bangladesh, Indonesia, Japan, Kuwait, Malaysia, Philippines, Singapore, Thailand, and Turkey) over 1988 to 2012, and showed that stock market and inflation of 16 countries had the long run equilibrium relationship. Granger causality test confirmed existence of a multitude of causal relations between two variables. Tripathi and Kumar (2014) studied the long term relationship between stock prices of BRICS markets and their inflation rates by utilizing Panel Co-integration test from March 2000 to September 2013, and indicated the significant negative relationship between stock index and inflation rate for Russia and Brazil. There was an inverse result in case of India and China. Based on evidence above we propose that the relationship between inflation and stock price in case of real estate sector exists.

Most of investors believed that the bonds are the direct substitute for stocks and the prices of stocks and bonds move in the opposite direction. The stock price goes down in recession economy stage; meanwhile bond investments become safer, especially for government bonds. It is expected that investors will shift their investment from stocks to government bonds, and as a result the bond price will increase, and the bond price has the inverse relationship with its yield, so there is a positive correlation between government bond yield and stock price. Over $20^{\text {th }}$ century, the correlation between US stocks and long term US treasury yields was negative, but this relationship was strongly positive in the 2000s in explanation of increasing in economic growth and expected dividends (Dick et al., 2013). In Japan, bond yields had a slightly negative liaison with stock prices in mid 1990s and relatively inverse correlation in the period of low inflation and economic saturation. Ewan, and Muhammad (2014) discovered the tendency of association of stock prices and bond yields in US and some developed countries such as Australia, Japan positively. From the argument mentioned above, we propose the hypothesis there is a significant relationship between bond yield and stock price.

The relation between stock prices and exchange rates has received concern of many researchers on the world. However, their studies have been divergent and failed to establish a clear relation between stock prices and exchange rates. The relationship is explained base on two models, "Flow oriented" and "Stock oriented". Flow oriented 
model estimates association of two variables base on the macroeconomic view (Dornbusch - Fisher, 1980). In particular, the changes in exchange rates affected international competitiveness and trade balance because the appreciation and depreciation of national currency affect export and import values of companies. Cash flows of companies with multinational activities would be affected as the exchange rates changed leading the change of stock value that determined as a present value of future cash flows of companies. Thus, flow oriented model implies a positive relationship between exchange rates and stock prices. In the contrary, according to Branson et al (1977) stock oriented model assumes the change in stock prices is affected by exchange rate negatively. Saadet Kasman (2003) employed daily closing prices of four aggregate indices: National 100, Financial Sector Index, Production Sector Index, Service Sector Index and daily TL/U.S. dollar exchange rate to analyze the relationship between stock price and exchange rate in Turkey from 1990 to 2002. By using unit root test, the co-integration result provided evidence of the same direction of exchange rate and stock prices and this relation existed stably in long run. Noel Dilrukshan Richards, John Simpson (2009) examined the nexus between stock prices and exchange rates through collecting the daily Australian stock prices and Australian - USD exchange rate from January 2003 to June 2006. This paper concluded that there is the short-term positive relationship between Australian exchange rate and stock prices during the sample period. Otherwise, Granger causality tests provided a unidirectional causal relationship between these variables with the significance level of 5\%.HakanAltin (2014) explored the relation between Borsa Istanbul (BIST 100) index and exchange rate of Turkey national currency and other currencies - EURO (EUR), United States Dollar (USD), Pound Sterling (GBP),
Japanese Yen (JPY), Australian Dollar (AUD), Canadian Dollar (CAD), and Swedish Krona (SEK) from 2001 to 2013. By using Vector Autoregressive Model (VAR), the study showed the significant long term relationship between BIST 100 and exchange rates. In particular, there is a positive correlation between BIST 100 stock market index and GBP and JPY at 5\% significant level. There is a negative correlation between BIST 100 stock market index and EUR and USD at 5\% significant level. There is no relationship between BIST 100 stock market index and other currencies at 5\% significant level. Based on these above arguments, we develop the hypothesis: the relationship between exchange rates and stock price exists.

Trading volume of certain stock reflects the liquidity risk of the stock; therefore it is a main concern of potential investors. Brailsford (1994) investigated the relation between trading volume and price movement in Australian stock market from April 1989 to December 1993 by applying GARCH model to analyze daily data. The result showed that there is significant correlation between trading volume and price change in both aggregate market and individual stocks. Kumar, Singh, and Pandey (2009) used the stock prices and trading volumes of 50 stocks in 21 sectors of the Indian economy to examine the causal relationship between two variables. The study found the positive and asymmetric association between volume and price changes. Moreover, VAR and Granger causality proved volume and returns of 50 Indian stocks had a bi-directional relation. Manex Yonis (2013) used 2600 observations of daily stock price indices and corresponding trading volume series from stock markets of four Asia Tiger economies (Hong Kong, Korea, Singapore, Taiwan), and USA stock market to discover the dynamic liaison between trading volume and stock returns. Using OLS and GMM test, the research determined the positive 
correlation between absolute returns and trading volume in U.S and four Tiger economies. MAGARCH model was employed to consolidate the positive relation between two variables in all countries, except for the case of Korea. In addition, VAR showed there was the bi-causal relationship between stock returns and trading volume in Singapore and Korea. Based on this evidence we propose the hypothesis that there is a significant relationship between stock trading volume and real estate stock price.

2.2. The overview of selected economic factors and real estate sector in Vietnam $(2008-2014)$

The change of selected economic factors: GDP, CPI, 10 year Government bond's interest rate, and exchange rate from 2008 to 2014 is described in Table 1, Figure $1 \& 2$ as below:

Table 1. GDP, CPI of Vietnam economy from 2008 to 2014

\begin{tabular}{|l|c|c|c|c|c|c|c|}
\hline Years/Items & 2008 & 2009 & 2010 & 2011 & 2012 & 2013 & 2014 \\
\hline GDP & $6.18 \%$ & $5.32 \%$ & $6.78 \%$ & $5.89 \%$ & $5.25 \%$ & $5.42 \%$ & $5.98 \%$ \\
\hline CPI & $22.97 \%$ & $6.88 \%$ & $9.19 \%$ & $18.58 \%$ & $9.21 \%$ & $6.6 \%$ & $4.09 \%$ \\
\hline
\end{tabular}

Source: www.gso.gov.vn

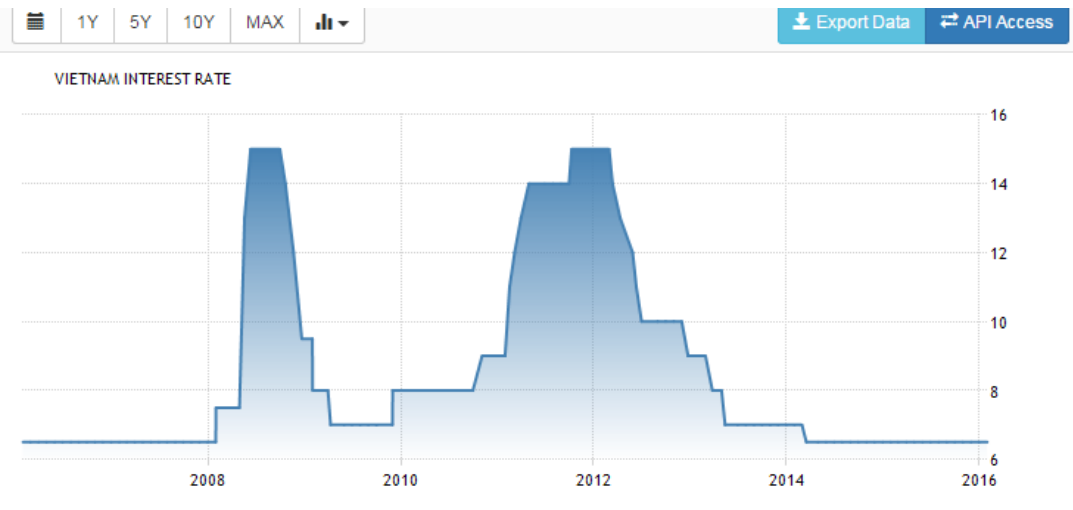

Figure 1. Vietnam interest rate from 2008 - 2015

Source: $w w w$. tradingeconomics.com

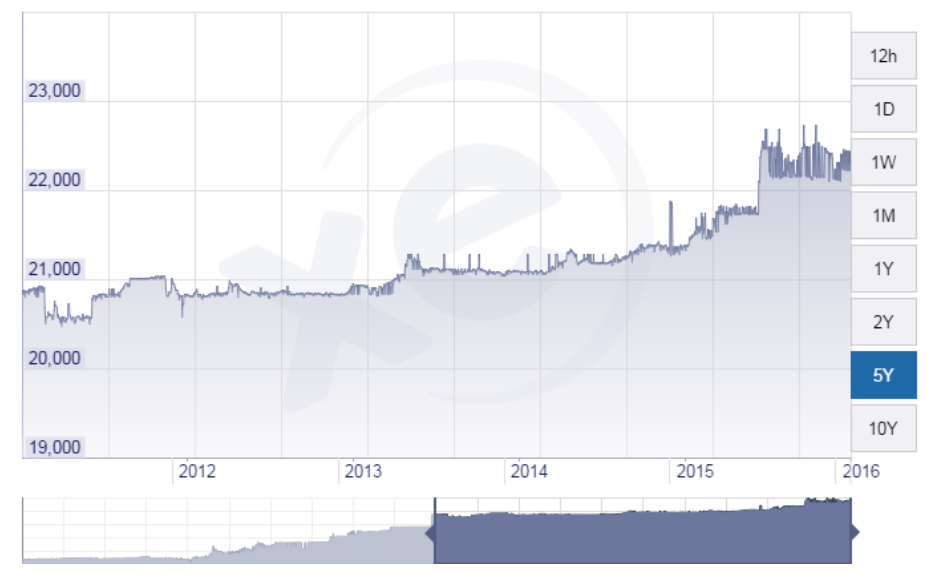

Figure 2. USD/VND exchange rate in period 2009 -2015

Source: www.xe.com 
Before 1990 Vietnamese economy was a centralized economy and less developed one. Real estate market was almost non-existent, so real estate transactions were implicit activities. In 1993, "First Fever" of the demand of residential houses and land happened and leading to the birth of the Land Law (1993). To prevent the speculation in real estate market, the Government issued two Decrees 18 and 87 (1995) on transferring the privilege of land use and land rental. Under the effect of the two Decrees, the wave of selling off land and house of speculators made real estate market fall into oversupply state, and plunged into debt. Meanwhile, the occurrence of Asia economic crisis originated from Thailand led to a large number of property projects invested by foreigners had failed and contributed significantly to the downturn of real estate market. In 2003, the number of successful real estate transactions decreased $28 \%$, and $56 \%$ in 2004, and continued went down $78 \%$ in 2005. The growth of FDI capital flows made the impressive economic growth from 2003 to 2007. In the period of (2006 - 2007), Vietnamese stock market developed strongly, and the harvesting of winner - investors in the market moved to the real estate market, especially apartment and villa segments. In 2008, Real estate market bubble happened along with the increasing of inflation terribly. Government regulated market by monetary policy on tight control credit, especially nonproduction credit to stabilize market and curb inflation. The tight fiscal policy leaded to sharply decrease in both price and transaction in real estate market. Decree 71 and 69 were born in 2010 which guided the implementation of the Land Law with amendments in 2009 and land tax collection made market more quietly. In 2011, Government issued Decree 11 to control inflation and stabilize macroeconomic environment. In addition, reduction in credit growth made the real estate market gloomier. In 2012, the number of bankruptcy and dissolution enterprises was highest in compared with previous years (VCCI [2012]).The competition in real estate industry in this year was really fierce. However, the sector has recovered rapidly from 2013 to now. In the Report on Business Registration in the first 7 months of 2015 of the State Administration for Business Registration under the Ministry of Planning and Investment, the real estate sector had 320 enterprises to suspend operations (down $25.1 \%$ from same period last year), 63 enterprises were dissolved (down $25 \%$ with the same period last year) and 175 enterprises came back in operation (not change). The number of new registered business operating in the real estate sector in the first seven months of 2015 rose $67.8 \%$ in comparing with the first six months of 2014. According to the Foreign Investment Agency, Ministry of Planning and Investment, on July $20^{\text {th }} 2015$, there were 1,068 new projects in the country with total registered capital amounted to 6.92 billion USD. Moreover, real estate field attained $19.3 \%$ of total investment capital, attracted 1.7 billion USD of FDI capital and became the second sector attracted the highest FDI capital in Vietnam.

\section{Research model and variable measurement}

To test the relationship between variables, the research model was developed as below:

$\mathrm{SR}_{\mathrm{i}, \mathrm{t}}=\beta_{0}+\beta_{1} * \mathrm{INF}_{\mathrm{i}, \mathrm{t}}+\beta_{2} *$ BO. Yie $\mathrm{i}_{\mathrm{i}, \mathrm{t}}+$ $\beta_{3} * \mathrm{GDP}_{\mathrm{i}, \mathrm{t}}+\beta_{4} * \mathrm{EXC}_{\mathrm{i}, \mathrm{t}}+\beta_{5} * \mathrm{Tra}_{\mathrm{Tol}} \mathrm{Vol}_{\mathrm{i}, \mathrm{t}}+\varepsilon_{\mathrm{i}, \mathrm{t}}$

Where:

$\beta_{0}$ : is the mean of $y$, when all independent variables equal zero

$\beta_{1}, \quad \beta_{2}, \beta_{3}, \quad \beta_{4}, \quad \beta_{5}, \quad \beta_{6}$ : correlation coefficients, indicate the relationship between independent variables and dependent variable.

$\boldsymbol{\varepsilon}_{\mathbf{i}, \mathrm{t}}$ : random error.

In which:

- $\mathrm{SR}_{\mathrm{i}, \mathrm{t}}$ : the monthly closing prices of 38 
listed Real estate companies on HOSE in subsectors list 2014 of HOSE

- $\mathrm{INF}_{\mathrm{i}, \mathrm{t}}$ : measured by the monthly CPI index of Vietnam

- BO.Yie: the monthly yields of Vietnam 10-year Government bond

- $\mathrm{GDP}_{\mathrm{i}, \mathrm{t}}$ : the monthly GDP growth rate of Vietnam

- $\mathrm{EXC}_{\mathrm{i}, \mathrm{t}}$ : is the USD/VND Exchange rate $(\mathrm{EXC})$

- Tra. Vol $_{i, t}$ : is the monthly trading volumes of 38 listed Real Estate companies on Ho Chi Minh stock exchange in subsectors list 2014 of HOSE.

\subsection{Choose the fitted model}

AIC (Akaike information criterion) is a measure of the relative quality of statistical models for a given set of data. Given a collection of models for the data, AIC estimates the quality of each model, relative to each of the other models. The model with the lowest AIC is preferred. In statistics, the Bayesian information criterion (BIC) is a criterion for model selection among a finite set of models; the model with the lowest BIC is preferred. Running the statistic tests resulted that the $\log -\log$ model has the lowest AIC and BIC value in four proposed models, it is 2.033 and -19096.73, respectively. Therefore, $\log -\log$ model is preferred to test the relationship between macroeconomic factors, stock trading volume and real estate stock prices. The model is presented as below:

$$
\operatorname{LogSR}_{\mathrm{i}, \mathrm{t}}=\beta_{0}+\beta_{1} * \log \mathrm{INF}_{\mathrm{i}, \mathrm{t}}+
$$

$\beta_{2} * \operatorname{logBO}$. Yie $_{\mathrm{i}, \mathrm{t}}+\beta_{3} * \log \mathrm{GDP}_{\mathrm{i}, \mathrm{t}}+$ $\beta_{4} * \log \mathrm{EXC}_{\mathrm{i}, \mathrm{t}}+\beta_{5} * \log \operatorname{Tra}_{\mathrm{Vol}} \mathrm{Vol}_{\mathrm{i}, \mathrm{t}}+\varepsilon_{\mathrm{i}, \mathrm{t}}$

The distribution of variables with the number of observation of 2583 is presented in Table 2.

Table 2. Descriptive Statistics

\begin{tabular}{|l|c|c|c|c|c|}
\hline Variable & Obs & Mean & Std.Dev & Min & Max \\
\hline logsr & 2583 & 2.755332 & .8570428 & .5068176 & 5.280408 \\
\hline logcpi & 2583 & 4.611077 & .0123609 & 4.564244 & 4.677491 \\
\hline logbondyie & 2583 & 2.240839 & .2001135 & 1.84055 & 2.516082 \\
\hline loggdp & 2583 & 1.746055 & .1422457 & 1.144223 & 2.017566 \\
\hline logexc & 2583 & 9.931628 & .0573628 & 9.580938 & 10.02194 \\
\hline
\end{tabular}

Stationary checking: TheIm - Pesaran - Shin test was employed to test for stationarity. The test results showed that all variables are stationary (Table 3) as a result of P-value smaller than 0.05 .

Table 3. The Unit root test result

\begin{tabular}{|c|c|}
\hline $\begin{array}{l}\text { H0: All panels contain unit roots } \\
\text { Ha: Some panels are stationary } \\
\text { AR parameter: Panel - specific } \\
\text { Panel means: Included } \\
\text { Time trend: Included } \\
\text { ADF regression: } 2 \text { lags }\end{array}$ & $\begin{array}{l}\text { Number of panels }=38 \\
\text { Avg. number of periods }=68.68 \\
\text { Asymptotics: } \mathrm{T}, \mathrm{N} \rightarrow \text { Infinity sequentially }\end{array}$ \\
\hline $\begin{array}{l}\text { Im - Pesaran }- \text { Shin unit root test for logsr } \\
\text { Statistic } \quad \mathrm{p}-\text { value } \\
\text { W-t-bar } \quad-6.2061 \quad 0.0000\end{array}$ & $\begin{array}{l}\text { Im }- \text { Pesaran }- \text { Shin unit root test for } \\
\text { logtravol } \\
\text { Statistic } \quad p \text {-value }\end{array}$ \\
\hline
\end{tabular}




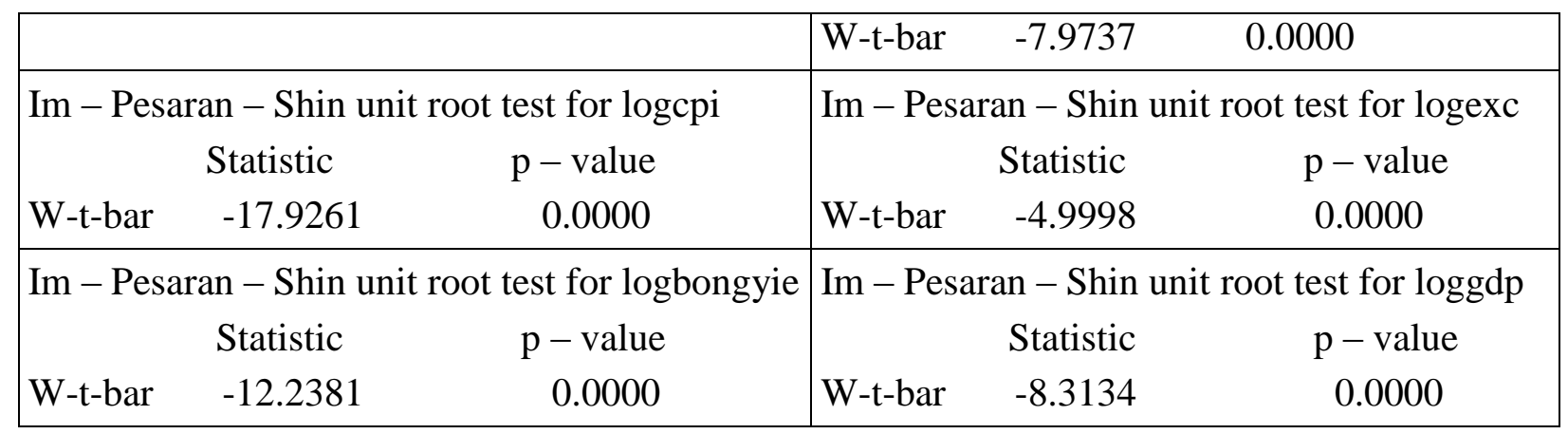

Source: Stata

3.2. Correlation analysis and Multicollinearity testing

The correlation matrix (Table 4) shows that almost correlation coefficient less than 0.5 , or most independent variables are not highly correlated except for the case of logexc and logsr.

Table 4. Correlation matrix

\begin{tabular}{lllllll} 
& logsr & logcpi & logbondyie & loggdp & logexc & logtravol \\
\hline logsr & 1.0000 & & & & & \\
logcpi & 0.0991 & 1.0000 & & & & \\
logbondyie & 0.2959 & 0.3090 & 1.0000 & & & \\
\hline loggdp & 0.2043 & 0.1064 & -0.1202 & 1.000 & 1.0000 & \\
\hline logexc & -0.5891 & -0.1309 & -0.4993 & -0.0235 & -0.2958 & 1.0000 \\
\hline logtravol & 0.0869 & 0.0671 & 0.2677 & -0.0564 & -0.000 \\
\hline
\end{tabular}

The testing result shows that no variable has VIF $>10$, so there is no multicollinearity in the model (Table 5).

Table 5. VIF test

\begin{tabular}{cc}
\hline Variable & VIF \\
\hline Logbondyie & 1.53 \\
Logexc & 1.40 \\
Logepi & 1.13 \\
Logtravol & 1.12 \\
Loggdp & 1.05 \\
Mean VIF & 1.25 \\
\hline
\end{tabular}

\subsection{Regression results}

3.3.1. The Pooled OLS Regression results (Table 6)

R-squared and adjusted R-squared of model is fairly good. The model explains around $39.15 \%$ of the variation in the dependent variable. Durbin Watson test is used to recognize the presence of autocorrelation between independent variables from a regression analysis. The Durbin Watson statistics is always between 0 and 4 . In this study, Durbin Watson has a value of 0.1063 which approaching 0 indicate that the positive correlation exists. 
Table 6. Regression with Pooled OLS model

\begin{tabular}{|l|c|c|c|}
\hline \multicolumn{4}{|c|}{ Dependent Variable: logsr } \\
\hline Variables & Coefficient & \multicolumn{1}{|c|}{ t-value } & Prob-values \\
\hline constant & 99.51391 & 16.20 & 0.000 \\
\hline $\operatorname{logcpi}$ & -.5891842 & -0.48 & 0.633 \\
\hline logbondyie & .2267488 & 2.93 & 0.003 \\
\hline $\operatorname{loggdp}$ & 1.159281 & 13.54 & 0.000 \\
\hline $\operatorname{logexc}$ & -9.689421 & -38.48 & 0.000 \\
\hline $\operatorname{logtravol}$ & -.0308675 & -5.73 & 0.000 \\
\hline $\mathrm{R}^{2}=0.3915$ & & $\begin{array}{l}\text { Durbin- Watson stat }=.1063754 \\
\text { Number of obs }=2583\end{array}$ & F-Stat (Prob-value) $=468.29(0.000)$ \\
\hline \multicolumn{4}{|c|}{$5 \%$ level of significance } \\
\hline
\end{tabular}

\subsubsection{The Fixed and Random Effect} Models Regression results (Table 7 and 8)

The fixed effects model is used to analyze the impact of variables over different time. The assumption of model is the correlation between entity's error term and predictor variables. Moreover, the model removes the effect of the time-invariant characteristics. If there are the differences across entities influencing on the dependent variable, random effects model should be used. In model, the variation across entities is assumed to be random and uncorrelated with the predictor or independent variable. To choose the fixed or random effects, Hausman test was run to test whether the unique errors $\left(\mathrm{u}_{\mathrm{i}}\right)$ are correlated with the regressors.

Table 7. Regression with fixed effect model

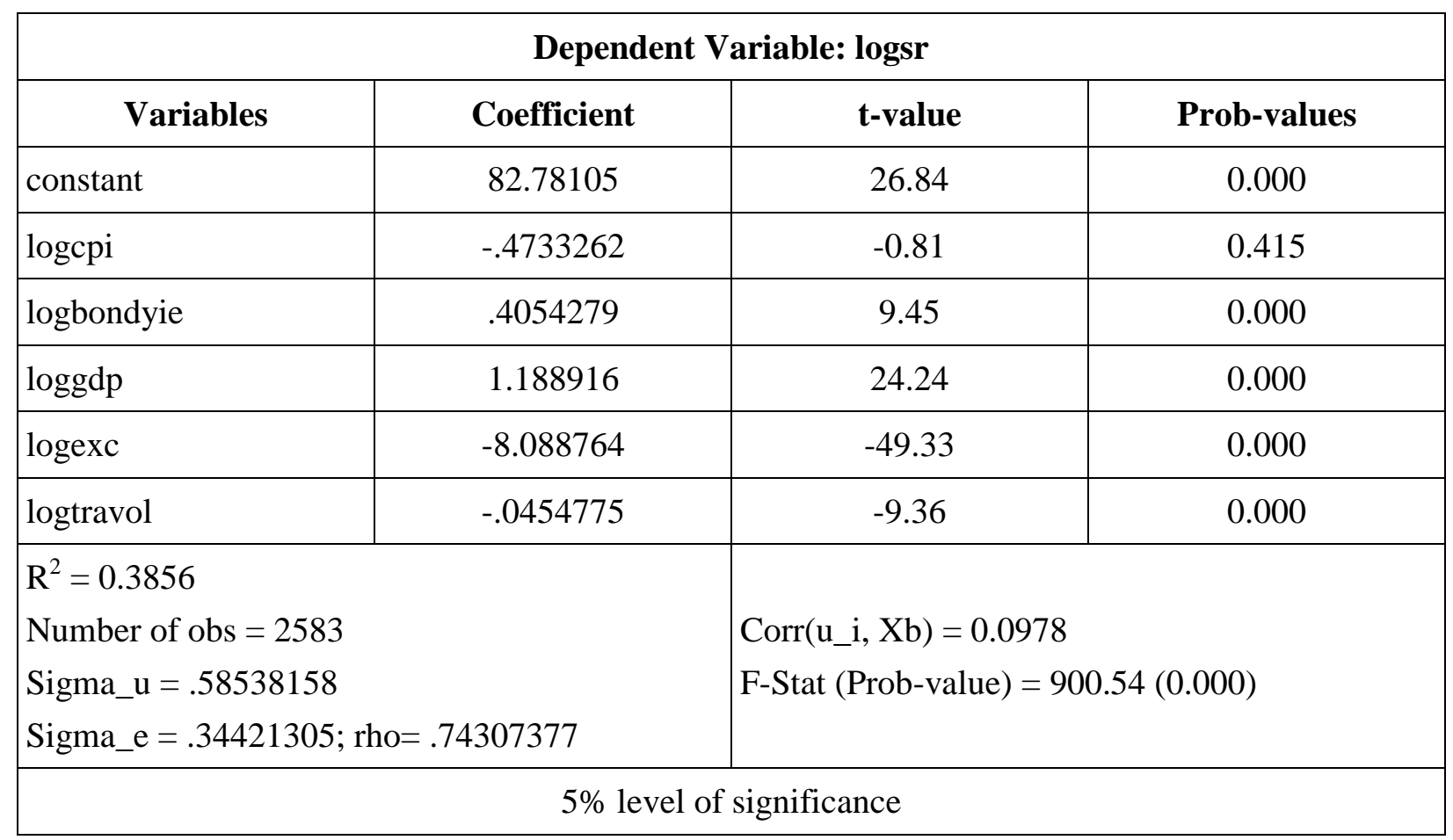


Table 8. Regression test with Random effect model

\begin{tabular}{|l|c|c|c|}
\hline \multicolumn{4}{|c|}{ Dependent Variable: logsr } \\
\hline \multicolumn{1}{|c|}{ Variables } & Coefficient & z-value & Prob-values \\
\hline constant & 82.86714 & 26.80 & 0.000 \\
\hline logcpi & -.4737664 & -0.81 & 0.416 \\
\hline logbondyie & .4037773 & 9.40 & 0.000 \\
\hline loggdp & 1.188791 & 24.18 & 0.000 \\
\hline logexc & -8.099889 & -49.30 & 0.000 \\
\hline logtravol & -.0453098 & -9.36 & 0.000 \\
\hline $\begin{array}{l}\mathrm{R}^{2}=0.3857 \\
\text { Number of obs }=2583 \\
\text { Sigma_u = .50251394 } \\
\text { Sigma_e }=.34421304 ; \text { rho }=.68064232\end{array}$ & $\begin{array}{l}\text { Corr(u_i, Xb) }=0 \text { (assumed) } \\
\text { Wald chi2 }=4491.47\end{array}$ \\
\hline \multicolumn{4}{|l}{$5 \%$ level of significance } \\
\hline
\end{tabular}

Hausman test's result showed that p-value smaller than 0.05 , the fixed effects model was chosen. This result is consolidated again by xtoverid command in stata software (0.0032).

Table 9. Hausman test result

\begin{tabular}{|c|c|c|c|c|}
\hline & $\begin{array}{c}\text { (b) } \\
\text { fixed }\end{array}$ & $\begin{array}{c}\text { (B) } \\
\text { random }\end{array}$ & $\begin{array}{c}\text { (b-B) } \\
\text { Difference }\end{array}$ & \multirow{3}{*}{$\operatorname{Chi} 2(5)=-1.28$} \\
\hline $\log c p i$ & -4733262 & -.4737664 & .0004402 & \\
\hline logbondyie & .4054279 & .4037773 & .0016506 & \\
\hline $\operatorname{loggdp}$ & 1.188916 & 1.188791 & .0001249 & \multirow{3}{*}{$\begin{array}{c}\mathbf{p}-\mathbf{v a l u e}=\mathbf{0 . 0 0 3 2} \\
(\text { xtoverid } \\
\text { command })\end{array}$} \\
\hline logexc & -8.088764 & -8.099889 & .011125 & \\
\hline logtravol & -.0454775 & -.0453098 & -.0001677 & \\
\hline
\end{tabular}

3.3.3. Heteroskedasticity testing in fixed effects model

Heteroskedasticity appears when the standard deviations of an observed variable over specific time period are non-constant.

Table 10. Heteroskedasticity Result

\begin{tabular}{|c|c|}
\hline \multicolumn{2}{|c|}{ H0: $\operatorname{sigma}(i)^{\wedge} 2=\operatorname{sigma}^{\wedge} 2$ for all $\mathrm{i}$} \\
\hline Chi2 $(\mathbf{3 8})=\mathbf{1 2 7 4 . 5 8}$ & Prob $>$ chi2 $=\mathbf{0 . 0 0 0 0}$ \\
\hline
\end{tabular}

The test result shows that null hypothesis is rejected at 5\% significant level or the changes in variance of observations exist.

3.3.4. The adjustment of the errors in fixed effects model

The model met Heteroskedasticity and the positive correlation that easily lead to the bias in the research result. To solve these problems, the fixed effects model was tested again with robust, wls0, and prais commands in stata.

Step 1: Run robust standard errors in fixed effects model 
Table 11. The fixed effects model, robust

\begin{tabular}{|c|c|c|c|}
\hline \multicolumn{4}{|c|}{ Dependent Variable: logsr } \\
\hline Variables & Coefficient & t-value & Prob-values \\
\hline constant & 82.78105 & 10.79 & 0.000 \\
\hline $\log c p i$ & -.4733262 & -1.21 & 0.233 \\
\hline logbondyie & .4054279 & 3.12 & 0.000 \\
\hline $\operatorname{loggdp}$ & 1.188916 & 13.04 & 0.000 \\
\hline logexc & -8.088764 & -11.15 & 0.000 \\
\hline logtravol & -.0454775 & -2.70 & 0.010 \\
\hline $\begin{array}{l}\mathrm{R}^{2}=0.3856 \\
\text { Number of obs }= \\
\text { Sigma_u }=.5853 \\
\text { Sigma_e }=.34213\end{array}$ & 4307377 & \multicolumn{2}{|c|}{$\begin{array}{l}\text { Corr }\left(u \_i, X b\right)=0.0978 \\
\text { F-Stat }(\text { Prob-value })=64.41(0.000)\end{array}$} \\
\hline
\end{tabular}

There is the difference between two results before and after robust standard errors. It considers the heteroskedaticity in this model.

Step 2: Weighted least squares provides one method for dealing with the existence of heterosdasticity in the model.

The test result showed that the heterosdasticity problem is solved with p-value of 0.668 , greater than 0.05 . Thus, the changes in variance of observations do not exist.

Table 12. Weighted Least Squared Regression

\begin{tabular}{|c|c|c|c|}
\hline Source & SS & df & MS \\
\hline Model & 266.419508 & 6 & 44.4032513 \\
\hline Residual & 1523.77533 & 2576 & .591527692 \\
\hline Total & 1790.19484 & 2582 & .693365 \\
\hline \multicolumn{4}{|c|}{ Dependent Variable: logsr } \\
\hline Variables & Coefficient & t-value & Prob-values \\
\hline constant & 1514.083 & 2.36 & 0.018 \\
\hline logcpi & -219.4836 & -2.38 & 0.017 \\
\hline logbondyie & 1.324468 & 15.68 & 0.000 \\
\hline loggdp & 1.426101 & 12.31 & 0.000 \\
\hline logtravol & .0056303 & 0.89 & 0.371 \\
\hline $\log c p i s q$ & -10732.64 & -2.35 & 0.019 \\
\hline logtravolsq & -.272066 & -1.71 & 0.087 \\
\hline \multicolumn{2}{|c|}{$\begin{array}{l}\mathrm{R}^{2}=0.1488 \\
\text { Adj } \mathrm{R} \text {-squared }=0.1468 \\
\text { Number of obs }=2583\end{array}$} & \multicolumn{2}{|c|}{$\begin{array}{l}\text { F-Stat }(\text { Prob-value })=75.07(0.000) \\
5 \% \text { level of significance }\end{array}$} \\
\hline \multicolumn{4}{|c|}{$\begin{array}{l}\text { H0: Constant variance } \\
\text { Variable: fitted values of logsr }\end{array}$} \\
\hline \multicolumn{2}{|c|}{ Chi2 $(1)=0.18$} & \multicolumn{2}{|c|}{ Prob $>$ chi2 $=0.6688$} \\
\hline
\end{tabular}


Step 3: The autocorrelation was corrected with research option of prais to search for the p-value that minimizes the sum-of squared of the Cochrane-Orcutt transformed equation. Normally, the default Prais-Winsten transformations is used with such a small dataset, but the less-efficient Cochrane-Orcutt transformation allows us to demonstrate an aspect of the estimator's convergence. The original Durbin Watson is 0.1063 which approaching 0 indicate the positive correlation. The transformed Durbin Watson is 1.809 which approaching 2 indicate no autocorrelation.

Table 13. Prais-Winsten transformations result

\begin{tabular}{|c|c|c|c|}
\hline \multicolumn{4}{|c|}{$\begin{array}{l}\text { Interation } 0: \mathrm{rho}=0.0000 \\
\text { Interation } 1: \mathrm{rho}=0.9514 \\
\text { Interation 2: } \mathrm{rho}=0.9607 \\
\text { Interation 3: } \mathrm{rho}=0.9609 \\
\text { Interation } 4: \mathrm{rho}=0.9609 \\
\text { Interation } 5: \mathrm{rho}=0.9609\end{array}$} \\
\hline \multicolumn{4}{|c|}{ Dependent Variable: logsr } \\
\hline Variables & Coefficient & t-value & Prob-values \\
\hline constant & 64.98842 & 15.88 & 0.000 \\
\hline $\operatorname{logcpi}$ & .5171464 & 2.27 & 0.023 \\
\hline logbondyie & .0594623 & 0.65 & 0.516 \\
\hline $\operatorname{loggdp}$ & .3870862 & 4.29 & 0.000 \\
\hline logexc & -6.576157 & -15.80 & 0.000 \\
\hline logtravol & & -.0012778 & 0.782 \\
\hline \multicolumn{2}{|l|}{$\begin{array}{l}\mathrm{R}^{2}=0.4576 \\
\text { Number of obs }=2583\end{array}$} & \multicolumn{2}{|c|}{$\begin{array}{l}\text { F-Stat }(\text { Prob-value })=51.49(0.000) \\
\text { Durbin }- \text { Watson Stat }=1.809897\end{array}$} \\
\hline
\end{tabular}

\section{Findings and discussion}

The study has some empirical finding as following:

There is a significant positive relationship between real estate stock prices and inflation rate $(\beta=.517, p<0.05)$. Examining the effect of inflation rate on stock price was done by many researchers, and brought about the differences in research's results. Most studies concluded that the expected inflation could either positively or negatively impact on stock prices, which depends on the performance of hedge funds and government's monetary policy. For real estate stock price, the relation could be explained by the positive effect of expected inflation on house price, in turn on the stock performance.

There is no a significant relationship between real estate stock prices and long-term government bond yield ( $\mathrm{p}=0.516>0.05$ ). The result is explained by the absence of developed corporate bond market in Vietnamese financial market.

There is a significant positive correlation between real estate stock prices and GDP growth rate $(\beta=.387, \mathrm{p}<0.01)$. The stock investors always try to look into the future economic growth to find opportunities and prevent riskiness. The stock prices reflect the investor's expectations for future economic growth. The GDP growth rate reflects the improvement of residents' wealth, in turn increases the demand of housing, and positive impact on real estate firms, then on real estate stock prices.

There is a significant negative relationship between real estate stock prices and USD/VND exchange rate $(\beta=-6.576$, 
$\mathrm{p}<0.01)$. Actually, real estate stocks are held by organizational foreign investors. As the exchange rate increases their portfolio's value decreases in USD. The foreign investors will sell their portfolio to prevent the value depreciated, in turn affect negatively on the stock prices.

There is no a significant relationship between real estate stock prices and stock trading volume $(\mathrm{p}>0.05)$.

\section{Conclusion and recommendation}

This study investigates the relationship of selected economic factors and real estate stock price with 2583 observations consist of 38 real estate companies listed on HOSE in period 7 years, from January 2009 to September 2015. After using Pooled OLS regression model, fixed effects model, random effects model, Hausman test, the study recognized the fixed effect model is the most feasible model to describe the relationship between real estate stock prices and the independent variables after satisfying the regression assumptions. The study found that 3 economic factors(inflation rate, GDP growth rate, and exchange rate)impact significantly on real estate stock prices; the relationship between Vietnam 10 years government bond yields and trading volume, and real estate stock prices no found.

Based on the research's result, we recommend that investors investing real estate stocks should consider these factors as predictors of real estate stock price movement.

\section{REFERENCES}

Brajesh Kumar, Priyanka Singh, and Ajay Pandey (2009). The Dynamic Relationship between

Price and Trding Volume: Evidence from Indian Stock Market. Research and Publications Paper, Vol.12, No.4, p. 2-35.

Branson, W., Halttunen, H. and Masson, P. (1977). Exchange rate in the short run: the dollar Deutsche mark rate. European Economic Review, 10, pp. 303-324.

Dornbusch, R. and Fischer, S. (1980). Exchange Rates and The Current Account. American Economic Review, Vol.70, No.5, pp. 960 - 971.

Ewan Rankin, Mulhummed Shah Idil (2014). A Century of Stock - Bond Correlations. Reserve Bank of Australia, Bulletin, $3^{\text {rd }}$ quarter 2014, pp. 67-74.

HakanAltin (2014). Stock Price and Exchange Rate: The Case of BIST 100. European Scientific Journal, Vol.10, No.16, p. $65-78$.

Manex Yonis (2013). Trading Volume and Stock Return: Empirical Evidence for Asian Tiger Economies. Master Thesis, 30 ECTS, p.1-68.

Noel Dilrukshan Richards, John Simpson (2009). The Interaction between Exchange Rates and Stock Prices: An Australian Context. International Journal of Economics and Finance, Vol.1, No.1, p. 3-23.

Pradhnan, et.al. (2013). The Impact of Stock Market Development on Inflation and Economic Growth of 16 Asian Countries: A Panel VAR Approach. Applied Econometrics and International Development, Vol.13, No.1, p. 203-220.

Saadet Kasman (2003). The Relationship between Exchange Rates and Stock Prices: A Causality Analysis. Cela Bayar University, p. 70-79. 
Timothy J. Brailsford (1994). The Empirical Relationship between Trading Volume, Returns and Volatility. Research Paper, Vol.94, No.1, p. 1-20.

Tripathi, V. \& Kumar, V. (2014). Relationship between Inflation and Stock Returns - Evidence from BRICS markets using Panel Co integration Test. International Journal of Accounting and Financial Reporting, Vol. 4, No. 2, p. 647-58.

Vanita Tripathi, Arnav Kumar (2014). Relationship between Inflation and Stock Returns Evidence from BRICS markets using Panel Co integration Test. International Journal of Accounting and Financial Reporting, Vol.4, No.2, p. 647-658. 